\title{
PENGARUH KEPERCAYAAN, KEMUDAHAN, DAN KEAMANAN TERHADAP KEPUTUSAN PEMBELIAN DI MARKETPLACE
}

\author{
Dian Agustiningrum \\ Universitas Negeri Surabaya \\ dyanayu322@gmail.com \\ Anik Lestari Andjarwati \\ Universitas Negeri Surabaya \\ aniklestari@unesa.ac.id
}

\begin{abstract}
This study aims to determine the effect of trust, comfort, and security on purchasing decisions at Shopee. With the development of an online shopping system that uses the internet, people are now following developments by having a mindset of consumer behaviour from conventional shopping to shopping digitally and online. Consumer confidence in online shopping through the system is very concerned about avoiding things that are not desirable. Therefore, it is necessary to ease of use of the system and strict security to conduct transactions online. The sample in this study were 200 respondents who were Shopee application users, both men and women aged 19-27 years. This study uses multiple linear regression analysis techniques through the analysis tool IBM SPSS statistic version 26. This study indicates that the variables of trust, security, and convenience affect purchasing decisions. The Shopee application is expected to further improve the quality of service through what consumers feel through reviews about the Shopee application in terms of the trust, convenience, and security or other things if it is deemed unsatisfactory. This study recommends marketers to maintain customer loyalty. The Shopee application must also maintain the ease of use of the application, such as the development of the latest features that are more attractive and practical to make it easier for consumers to search for products until they decide to make transactions.
\end{abstract}

Keywords: easy; e-commerce; purchase decision; security; trust.

\section{PENDAHULUAN}

Perdagangan elektronik atau e-commerce kini menjadi platform bisnis yang memiliki peluang sangat bagus untuk menjalankan bisnis bagi pelaku bisnis pada industri perdagangan online. Indonesia menjadi negara yang menginjak tingkat adopsi e-commerce tertinggi di tahun 2019. Pengguna $e$ commerce yaitu sebanyak 90 persen dari pengguna pada usia 19-45 tahun yang mengaplikasikan $e$ commerce sebagai media transaksi online baik pembelian produk maupun jasa (Husain, 2020). Dengan adanya perdagangan elektronik atau e-commerce, masyarakat Indonesia banyak yang melakukan belanja online, hal ini diprediksi pada tahun 2025 kegiatan transaksi melalui media internet di Indonesia akan mengalami pertumbuhan 3,7 kali lipat (Cindy, 2020).

Turban et al. (2015) menyatakan bahwa faktor utama yang memengaruhi keputusan pembelian adalah faktor karakteristik konsumen (consumer characteristic), faktor pedagang dan perantara transaksi (merchant and intermediary related), faktor produk dan layanan, serta faktor sistem penjualan (EC System). Variabel kepercayaan termasuk ke dalam faktor karakteristik konsumen (consumer characteristic) dan kemudahan serta keamanan terdapat pada faktor sistem penjualan (EC System). Kepercayaan dalam model perilaku konsumen online adalah hal yang dapat memengaruhi tingkah laku konsumen untuk menentukan keputusan pembelian (Turban et al., 2015:408). Penelitian Chin et al. (2009) mengatakan bahwa kepercayaan berpengaruh terhadap keputusan pembelian. Namun berbeda dengan penelitian Mbete \& Tanamal (2020) yang menunjukkan tidak ada pengaruh kepercayaan terhadap keputusan pembelian. Kemudahan yang ada pada model perilaku konsumen online adalah termasuk faktor yang memengaruhi keputusan pembelian online (Turban et al., 2015:408). Rachmawati et al. (2020) mengatakan kemudahan penggunaan memiliki pengaruh signifikan terhadap keputusan pembelian. Namun, Hernandez et al. (2009) menyebutkan kemudahan tidak berpengaruh signifikan terhadap keputusan pembelian. Keamanan dalam model perilaku konsumen online menjadi faktor utama yang memengaruhi keputusan pembelian online (Turban et 
Dian Agustiningrum \& Anik Lestari Andjarwati. Pengaruh Kepercayaan, Kemudahan, dan Keamanan terhadap Keputusan Pembelian di Marketplace

al., 2015:408). Dalam penelitian Raman \& A (2011), keputusan pembelian dipengaruhi secara signifikan oleh keamanan. Namun bertentangan dengan Irawan (2018), pengaruh keamanan terhadap keputusan pembelian tidak berpengaruh secara signifikan.

Shopee merupakan marketplace baru yang dirilis pada 2015 (Abraham, 2020). Shopee adalah marketplace yang baru muncul dibandingkan dengan beberapa marketplace lain yang lebih dahulu rilis seperti Tokopedia ada yang ada sejak tahun 2009. Kini, Shopee termasuk dalam marketplace yang sudah berhasil menembus ke dalam kategori marketplace terpopuler di Indonesia (Databoks, 2020). Tokopedia menjadi marketplace paling unggul di Indonesia sejak Q4 2018 hingga Q3 2019 dibandingkan Shopee yaitu dengan jumlah kunjungan web tertinggi sebanyak 65.953.400 pada Q3 2019. Namun, pada Q4 2019 hingga Q2 2020, Shopee menempati peringkat lebih unggul daripada Tokopedia yang memiliki jumlah pengunjung web sebanyak 96,532,300 pada Q3 2020 (Iprice, 2020). Dari hasil observasi awal, meskipun Shopee menduduki peringkat pertama marketplace di Indonesia, pada kenyataanya Shopee masih memiliki ulasan komentar konsumen terendah bintang 1 di App Store \& Play Store dibandingkan marketplace yang lain, seperti Tokopedia yang memiliki ulasan konsumen terendah bintang 1 lebih sedikit dibandingkan Shopee.

Penelitian ini bertujuan untuk mengetahui adanya hubungan kepercayaan, kemudahan, dan keamanan terhadap keputusan pembelian di marketplace.

\section{KAJIAN PUSTAKA DAN PENGEMBANGAN HIPOTESIS}

\section{Keputusan Pembelian (Purchase Decision)}

Keputusan pembelian adalah transaksi yang dilakukan melalui media internet dengan seseorang yang memiliki pilihan alternatif terkait produk atau jasa (Devaraj et al., 2003). Lebih lanjut menurut Suhari (2010) purchase decision adalah proses yang dilakukan individu dengan mengaplikasikan media sosial sebagai penentuan keputusan transaksi produk atau jasa yang disadari individu untuk memperoleh informasi tertentu. Terdapat lima tahapan pengambilan keputusan konsumen yang dikemukakan oleh Turban et al. (2015:408) yaitu sebagai berikut. (1) Pengenalan masalah, hal ini terjadi karena konsumen berada pada celah pilihan kondisi yang dialami dengan hal yang diinginkan. (2) Informasi, konsumen telah mengetahui kebutuhan yang diinginkan sehingga konsumen mulai mencari informasi yang sesuai dari berbagai sumber. (3) Evaluasi alternatif, konsumen memiliki alternatif yang akan disesuaikan dengan keinginannya. (4) Pengambilan keputusan, konsumen telah memutuskan untuk melakukan transaksi pembelian produk atau jasa. (5) Perilaku pasca pembelian, dalam tahap akhir ini konsumen dapat menentukan tingkat kepuasan yang dirasakan. Jika konsumen puas, terjadi loyalitas, sedangkan jika konsumen tidak puas, loyalitas pelanggan akan menurun. Indikator yang digunakan untuk mengukur variabel keputusan pembelian menggunakan indikator dari penelitian Kim et al. (2008) dan Devaraj et al. (2003) yang meliputi information quality, benefit, dan value.

\section{Kepercayaan (Trust)}

McKnight et al. (2002) menyatakan bahwa trust memiliki arti yaitu suatu keyakinan konsumen pada kemampuan penjual dalam situasi tertentu, kesanggupan menerima resiko apapun juga kesediaan untuk memberikan informasi mengenai dirinya pada saat transaksi online. Lebih lanjut, menurut Martínez \& Bosque (2013), kepercayaan online didefinisikan sebagai tingkat kesadaran yang dimiliki pelanggan dalam pertukaran transaksi online, atau dalam saluran pertukaran online. Kepercayaan merupakan hal tepenting yang diharapkan oleh konsumen untuk memenuhi keinginan yang sesuai dengan harapannya.

Kepercayaan dapat diukur melalui bentuk keyakinan pelanggan pada integritas, kebajikan, dan k emampuan perusahaan (Koufaris \& Hampton-Sosa 2004). Kepercayaan memiliki hal yang menimbulkan efek positif pada sikap pelanggan terhadap perusahaan dan konsumen yang memiliki rasa percaya pada perusahaan dapat lebih memiliki keputusan untuk membeli produk maupun jasa dari situs web perusahaan itu sendiri. Butir pernyataan untuk mengukur variabel kepercayaan online mengacu pada Koufaris \& Hampton-Sosa (2004) dan Flavián \& Guinalíu (2006), yang meliputi: 
perusahaan ini terpercaya, saya percaya perusahaan ini dengan sepenuh hati, situs web ini tidak membuat pernyataan palsu, situs web ini memiliki ciri kejujuran yang ditawarkan kepada konsumen, dan kejelasan layanan yang ditawarkannya kepada konsumen.

\section{Kemudahan (Ease)}

Davis (1989) mengartikan kemudahan penggunaan sebagai pengoperasian suatu sistem yang memiliki tingkat kemudahan untuk dilakukan seseorang dalam melakukan sesuatu. Davis (1989) mempromosikan aplikasi yaitu TAM (Technology Acceptance Model) yang bertujuan untuk mengetahui respon yang dirasakan pengguna terhadap kemudahan teknologi. Sedangkan menurut Turban et al. (2015), kemudahan penggunaan merupakan suatu hal yang dapat memengaruhi kepercayaan seseorang apabila sistem informasi mudah dioperasikan dan dipahami.

Menurut Venkatesh (2000), dimensi kemudahan penggunaan dibagi menjadi berikut: sistem yang jelas dan dapat dimengerti dapat memudahkan interaksi, meminimalisir usaha untuk berinteraksi dengan sistem, dan mudah mengaplikasikan sistem yang dikerjakan individu. Kemudahan penggunanaan sistem dapat menjadi salah satu nilai penting untuk menentukan keputusan, dikarenakan konsumen lebih nyaman menggunakan sistem yang lebih mudah dan lebih praktis. Item dalam penelitian ini menggunakan instrumen penelitian Smith (2008) dan Mbete \& Tanamal (2020) yang meliputi: saya merasa mudah menggunakan toko online untuk mendapatkan apa yang diinginkan, interaksi saya dengan toko online jelas dan dapat dimengerti, aplikasi Shopee memudahkan dalam memesan produk, aplikasi Shopee memudahkan pembayaran produk, dan aplikasi Shopee memudahkan dalam pengiriman produk.

\section{Keamanan (Security)}

Raman \& A (2011) mengatakan keamanan yaitu sebagai kunci yang menjadi perhatian konsumen untuk mengoperasikan internet dalam melakukan pembelian online melalui media sosial karena sebagian besar transaksi dilakukan di web. Lebih lanjut, menurut Yenisey et al. (2005), keamanan didefinisikan sebagai seberapa besar tingkat keamanan yang dirasakan oleh pengguna saat melakukan keputusan berbelanja melalui situs internet. Keamanan dalam dunia online menjadi faktor terpenting, karena saat ini banyak platfrom belanja online yang masih kurang memperhatikan keamanan para konsumennya seperti kebocoran data konsumen. Hal ini menjadi faktor terpenting konsumen untuk mempertimbangkan keputusannya.

Menurut Kolsaker \& Payne (2002), keamanan dapat dikatakan mencerminkan presepsi kehandalan dalam metode pembayaran yang dan mekanisme transmisi data serta penyimpanan. Dalam $e$ commerce, transaksi sering dilakukan dengan tanpa mengenal antara pembeli dan penjual. Maka dari itu, konsumen dapat merasa yakin ketika melakukan transaksi di e-commerce. Penelitian ini menggunakan item penelitian Flavián \& Guinalíu (2006) dan Aggarwal \& Rahul (2018) yang meliputi: saya rasa situs web ini memiliki mekanisme untuk memastikan informasi penggunanya dengan aman, saya rasa situs web ini menunjukkan perhatian besar terhadap keamanan transaksi apapun, situs ini melindungi informasi pembelian pribadi, situs ini tidak menggunakan informasi pelanggan secara ilegal, dan saya merasakan keamanan transaksi dengan menggunakan situs web.

\section{Hubungan antar Variabel}

Kepercayaan adalah suatu bentuk keyakinan konsumen terhadap kemampuan penjual untuk melakukan transaksi online dengan kesediaan konsumen untuk menerima resiko yang dapat mengancam keamanan pribadi dan kesanggupan konsumen memberikan informasi pribadi ketika melakukan transaksi online (McKnight et al., 2002). Lebih lanjut, menurut Martínez \& Bosque (2013), kepercayaan online didefinisikan sebagai tingkat kesadaran yang dimiliki pelanggan dalam pertukaran transaksi online, atau dalam saluran pertukaran online. Beberapa penelitian terdahulu telah membuktikan kepercayaan berpengaruh terhadap keputusan pembelian (Chin et al., 2009; Suhardi \& Taufik 2018; Osly \& Choirunnisa 2017). Hal ini bertentangan dengan penelitian Mbete \& Tanamal (2020) yang memiliki hasil penelitian yang sebaliknya yaitu tidak berpengaruh. 
Dian Agustiningrum \& Anik Lestari Andjarwati. Pengaruh Kepercayaan, Kemudahan, dan Keamanan terhadap Keputusan Pembelian di Marketplace

H1: Terdapat pengaruh positif kepercayaan terhadap keputusan pembelian.

Tingkat yang dirasakan seseorang menggunakan sistem tertentu dan dapat mengurangi usaha seseorang dalam mengerjakan atau melakukan sesuatu merupakan pengertian kemudahan penggunaan Davis (1989). Sedangkan menurut Turban et al. (2015), kemudahan merupakan suatu hal yang dapat memengaruhi kepercayaan pengguna sistem bahwa informasi mudah dipahami, lebih fleksibel dan mudah dioperasikan seperti karakteristik kemudahan penggunaan. Penelitian sebelumnya menunjukkan bahwa kemudahan berpengaruh terhadap keputusan pembelian (Rachmawati et al., 2020; Mbete \& Tanamal 2020; Osly \& Choirunnisa, 2017), namun berbeda dengan penelitian oleh Hernandez et al. (2009) bahwa kemudahan memiliki hasil yang berbeda atau tidak berpengaruh.

H2: Terdapat pengaruh positif kemudahan terhadap keputusan pembelian.

Menurut Raman \& A (2011), keamanan adalah kunci utama yang menjadi perhatian seseorang untuk melakukan pembelian online melalui media sosial, karena sebagian besar transaksi dilakukan di web. Lebih lanjut menurut Yenisey et al. (2005) keamanan didefinisikan sebagai seberapa besar tingkat keamanan yang dirasakan oleh pengguna saat melakukan keputusan berbelanja melalui situs internet. Penelitian sebelumnya telah membuktikan keamanan berpengaruh terhadap keputusan pembelian (Raman \& A, 2011; Asyari, 2018), namun berbeda dengan penelitian Irawan (2018) yang membuktikan sebaliknya yaitu tidak berpengaruh.

H3: Terdapat pengaruh positif keamanan terhadap keputusan pembelian.

Rancangan penelitian yang digunakan untuk mengetahui pengaruh kepercayaan, kemudahan, dan keamanan terhadap keputusan pembelian di Shopee ditunjukkan pada Gambar 1.

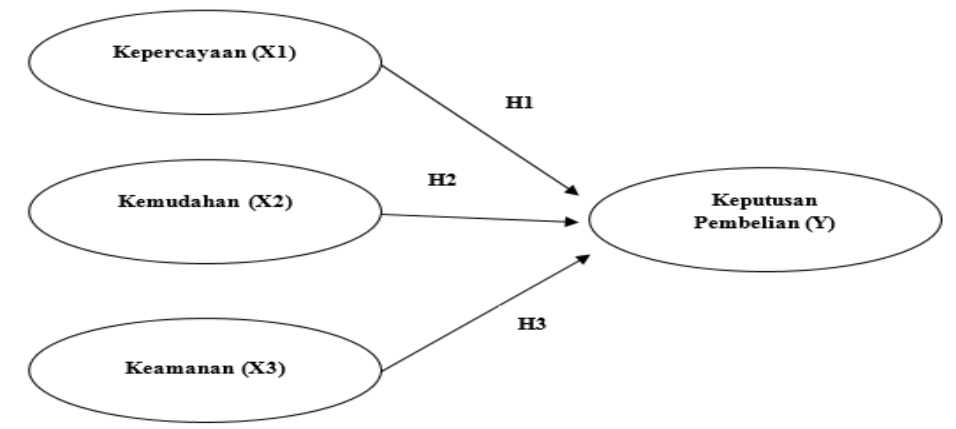

Gambar 1. KERANGKA PENELITIAN

\section{METODE PENELITIAN}

Penelitian dilakukan menggunakan pendekatan kuantitatif dengan jenis penelitian konklusif yang digunakan untuk menguji hipotesis (Malhotra, 2017:90). Data primer diperoleh dari jawaban responden yang telah disebarkan melalui angket dan data sekunder yang diperoleh dari studi literatur atau pencarian internet adalah sumber data yang digunakan dalam penelitian.

Populasi penelitian ini bersifat infinite dengan karakteristik respondenya yaitu pengguna aplikasi Shopee baik pria atau wanita yang berusia 19-45 tahun yang telah melakukan pembelian pada aplikasi Shopee. Terdapat 200 responden yang dikumpulkan menggunakan metode non-probability sampling. Angket disusun dengan menggunakan Google Form, kemudian data disebarkan secara online dengan cara melakukan broadcast di media sosial, yaitu Whatsapp, Instagram, dan Twitter. Butir pernyataan dalam angket diukur menggunakan teknik skala Likert berskala lima. Lalu, instrumen diuji menggunakan uji validitas dan reliabilitas terlebih dahulu. Selanjutnya, data dianalisis dan diolah menggunakan teknik regresi linier berganda melalui alat analisis IBM SPSS statistic versi 26. 


\section{Tabel 1. \\ HASIL UJI VALIDITAS DAN RELIABILITAS}

\begin{tabular}{|c|c|c|}
\hline Variabel dan Pernyataan & $\begin{array}{l}\text { Correlated } \\
\text { Item Total }\end{array}$ & $\begin{array}{l}\text { Cronbach's } \\
\text { Alpha }\end{array}$ \\
\hline \multicolumn{3}{|l|}{ Kepercayaan (Trust) } \\
\hline Aplikasi Shopee ini lebih terpercaya dibandingkan marketplace lain. & 0,786 & 0,873 \\
\hline Saya percaya aplikasi Shopee ini dengan sepenuh hati. & 0,712 & \\
\hline Saya rasa saya bisa yakin dengan janji yang dibuat aplikasi Shopee ini. & 0,761 & \\
\hline $\begin{array}{l}\text { Aplikasi Shopee ini memiliki kejujuran layanan yang ditawarkannya } \\
\text { kepada konsumen. }\end{array}$ & 0,713 & \\
\hline $\begin{array}{l}\text { Aplikasi Shopee ini memiliki kejelasan layanan yang ditawarkannya } \\
\text { kepada konsumen. }\end{array}$ & 0,619 & \\
\hline \multicolumn{3}{|l|}{ Kemudahan (Ease) } \\
\hline $\begin{array}{l}\text { Saya merasa mudah menggunakan aplikasi Shopee untuk menemukan apa } \\
\text { yang saya inginkan. }\end{array}$ & 0,656 & 0,811 \\
\hline Interaksi saya dengan aplikasi Shopee jelas dan dapat dimengerti. & 0,656 & \\
\hline Aplikasi Shopee memudahkan dalam memesan produk. & 0,686 & \\
\hline Aplikasi Shopee memudahkan pembayaran produk. & 0,587 & \\
\hline $\begin{array}{l}\text { Aplikasi Shopee memudahkan dalam menyesuaikan layanan pengiriman } \\
\text { produk. }\end{array}$ & 0,553 & \\
\hline \multicolumn{3}{|l|}{ Keamanan (Security) } \\
\hline $\begin{array}{l}\text { Saya rasa aplikasi Shopee memiliki mekanisme untuk memastikan } \\
\text { keamanan informasi penggunanya. }\end{array}$ & 0,704 & 0,772 \\
\hline $\begin{array}{l}\text { Saya rasa aplikasi Shopee menunjukkan perhatian besar terhadap } \\
\text { keamanan transaksi apapun. }\end{array}$ & 0,562 & \\
\hline Aplikasi Shopee melindungi informasi setiap penggunanya. & 0,717 & \\
\hline Aplikasi Shopee tidak menggunakan informasi pelanggan secara ilegal. & 0,682 & \\
\hline Saya merasa aman dalam transaksi saya dengan aplikasi Shopee. & 0,597 & \\
\hline \multicolumn{3}{|l|}{ Keputusan Pembelian (Purchase Decision) } \\
\hline $\begin{array}{l}\text { Aplikasi Shopee memiliki informasi yang baik tentang barang yang ingin } \\
\text { dibeli. }\end{array}$ & 0,547 & 0,828 \\
\hline Aplikasi Shopee memberikan informasi yang bermanfaat. & 0,635 & \\
\hline $\begin{array}{l}\text { Aplikasi Shopee memberikan informasi yang cukup pada saat melakukan } \\
\text { transaksi. }\end{array}$ & 0,709 & \\
\hline Saya merasa nyaman menggunakan aplikasi Shopee. & 0,514 & \\
\hline $\begin{array}{l}\text { Saya merasa dapat menghemat uang ketuka menggunakan aplikasi } \\
\text { Shopee. }\end{array}$ & 0,746 & \\
\hline Saya dapat menghemat waktu dengan menggunakan aplikasi Shopee. & 0,697 & \\
\hline Harga yang ditawarkan aplikasi Shopee bersaing. & 0,612 & \\
\hline Kualitas yang ditawarkan aplikasi Shopee sangat baik. & 0,633 & \\
\hline Fasilitas yang ditawarkan aplikasi Shopee memuaskan. & 0,591 & \\
\hline
\end{tabular}

Sumber: Data diolah (2021)

\section{HASIL DAN PEMBAHASAN}

\section{Profil Responden}

Data telah terkumpul sebanyak 200 responden yang berpartisipasi dalam penelitian ini. Perolehan jumlah responden pria sebanyak 30 orang (15\%), sedangkan perolehan responden wanita 170 orang (85\%). Berdasarkan karakteristik usia, mayoritas responden berusia 19-27 tahun dengan jumlah 178 (89\%), 28-35 tahun dengan jumlah 18 (9\%), dan usia 36-45 tahun dengan jumlah 4 (2\%). Responden didominasi oleh mahasiswa dengan jumlah 133 (66,5\%), sisanya didominasi profesi lain. 
Dian Agustiningrum \& Anik Lestari Andjarwati. Pengaruh Kepercayaan, Kemudahan, dan Keamanan terhadap Keputusan Pembelian di Marketplace

\section{Uji Validitas dan Reliabilitas}

Data akan dianalisis apabila sudah dilakukan uji validitas dan reliabilitas, Sebelumnya telah dilakukan penyebaran kuesioner kepada 30 responden secara online untuk diuji validitas dan reliabiltasnya. Item pertanyaan dapat dikatakan valid apabila nilai correlated item total $>0,3$ dan reliabel apabila nilai cronbach alpha $>0,7$. Berdasarkan Tabel 1, analisis uji validitas memiliki hasil seluruh item dalam kuesioner penelitian terbukti valid karena nilai r-hitung $\geq 0,3$. Uji reliabilitas menunjukkan hasil seluruh variabel di dalam penelitian ini memiliki nilai $\geq 0,7$ sehingga item pernyataan dalam seluruh variabel dinyatakan valid dan reliabel untuk digunakan menguji penelitian ini.

\section{Uji Asumsi Klasik}

Data yang terkumpul dianalisis untuk memastikan bahwa variabel telah berdistribusi normal dan tidak mengandung outlier untuk menghindari adanya bias di dalam analisis data. Hasil uji normalitas memiliki nilai signifikasi asymp sig. (2-tailed) $\geq 0,05$ yaitu 0,200 yang artinya data berdistribusi normal. Hasil uji multikolonieritas memiliki nilai dari variabel kepercayaan yaitu $0.588 \geq 0,01$, variabel kemudahan sebesar $0.658 \geq 0,01$, dan variabel keamanan yaitu $0.596 \geq 0,01$. Dapat diketahui jika antar variabel indenpenden tidak terjadi multikolonieritas. Pada setiap variabel independen, jika dilihat dari nilai VIF tidak terjadi gejala multikolonieritas. Nilai VIF variabel kepercayaan yaitu 1.700 $\leq 10$, variabel kemudahan sebesar $1.519 \leq 10$, dan variabel keamanan yaitu $1.667 \leq 10$. Artinya, tidak ada korelasi kuat antar variabel independen dalam penelitian. Maka, model regresi ini dapat ditoleransi. Hasil pada uji heteroskedastisitas menunjukkan setiap variabel memiliki nilai signifikan $\geq$ 0,05 .

\section{Analisis Regresi Linier Berganda}

Penelitian telah dilengkapi uji asumsi klasik yang kemudian dilakukan olah data dengan teknik regresi linier berganda yang bertujuan untuk mengetahui pengaruh antara variabel kepercayaan, kemudahan, dan keamanan terhadap keputusan pembelian. Berdasarkan Tabel 2, diperoleh persamaan (1).

$$
Y=3,829+0,518 X 1+0,602 X 2+0,448 X
$$

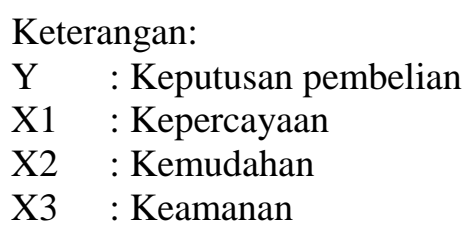

Dari persamaan (1), kepercayaan mengalami kenaikan sebesar satu satuan akan meningkatkan keputusan pembelian sebesar 0,518, kemudahan akan meningkat sebesar 0,602, keamanan akan meningkat 0,448 koefisien bernilai positif. Berdasarkan hasil uji analisis di atas, kemudahan memiliki pengaruh yang lebih besar yaitu 0,602. Selain itu, hasil uji t membuktikan adanya pengaruh kepercayaan, kemudahan, dan keamanan terhadap keputusan pembelian.

\section{Uji Kelayakan Model}

Berdasarkan hasil penelitian, nilai $\mathrm{R}^{2}$ sebesar $0,602=60,2 \%$. Dari nilai tersebut menunjukkan kontribusi untuk variabel independen terhadap variabel dependen dengan nilai sebesar 0,602. Artinya kepercayaan, kemudahan, dan keamanan memiliki pengaruh pada keputusan pembelian sebesar $60,2 \%$. Sisanya menggunakan variabel lain yang tidak digunakan dalam penelitian. Pada penelitian ini, kemudahan menjadi variabel yang memiliki pengaruh paling besar terhadap keputusan pembelian dibandingkan dengan kepercayaan dan keamanan.

\section{Uji Hipotesis}

Hasil analisis regresi linier berganda hipotesis pertama (H1) menunjukkan nilai t hitung untuk variabel kepercayaan sebesar 5,480, hipotesis kedua (H2) yaitu variabel kemudahan yang menunjukkan hasil dengan nilai sebesar 6,095, dan hipotesis ketiga (H3) memiliki nilai sebesar 4,626. Ketiga variabel independen memiliki nilai signifikansi yang sama yaitu ,000, artinya lebih kecil dari 0,05 atau $5 \%$ dan semua hipotesis dapat dikatakan $\mathrm{H}_{0}$ ditolak. Berdasarkan Tabel 2, diperoleh hasil 
bahwa H1, H2, dan $\mathrm{H} 3$ dapat diterima. Hal ini membuktikan adanya pengaruh kepercayaan, kemudahan, dan keamanan terhadap keputusan pembelian.

Tabel 2

HASIL ANALISIS REGRESI LINIER BERGANDA

\begin{tabular}{llrrrrr}
\hline \multirow{2}{*}{ Model } & \multicolumn{2}{c}{ Unstandardized Coefficients } & Standardized Coefficients & \multirow{2}{*}{ T } & \multirow{2}{*}{ Sig. } \\
\hline 1 & B & Std. Error & & & & \\
& (Constant) & 3.829 & 1.965 & & .948 & .053 \\
X1 & .518 & .094 & .322 & 5.480 & .000 \\
X2 & .602 & .099 & .339 & 6.095 & .000 \\
X3 & .448 & .097 & .270 & 4.626 & .000 \\
\hline
\end{tabular}

Sumber: Output SPSS (2021, data diolah)

\section{Pengaruh Kepercayaan terhadap Keputusan Pembelian}

Telah diperoleh hasil penelitian bahwa variabel kepercayaan berpengaruh terhadap keputusan pembelian. Hasil tersebut membuktikan hipotesis pertama yaitu terdapat pengaruh signifikan kepercayaan terhadap keputusan pembelian di aplikasi Shopee. Penelitian ini menunjukkan hasil yang sama dengan konsep yang dikemukakan Turban et al. (2015:408) bahwa kepercayaan konsumen memiliki pengaruh pada keputusan pembelian. Shopee membangun kepercayaan konsumen melalui peningkatan kualitas layanan fitur terbaru yang menarik seperti gratis ongkir yang menjajikan konsumen untuk melakukan transaksi pembelian dan memberikan jaminan keamanan mulai dari transaksi yang aman hingga kenyamanan dalam berinteraksi dengan penjual di aplikasi Shopee. Sejalan dengan penelitian Chin et al. (2009) yang menyatakan bahwa kepercayaan secara positif memengaruhi keputusan pembelian. Berbeda dengan penelitian oleh Mbete \& Tanamal (2020), kepercayaan memiliki pengaruh tidak signifikan terhadap keputusan pembelian di aplikasi Shopee. Hal ini dikarenakan penelitian tersebut menggunakan populasi khusus di area Surabaya sedangkan penelitian ini menggunakan populasi di seluruh Indonesia yang lebih luas sehingga dari segi respon responden memiliki jumlah yang jauh berbeda.

Berdasarkan hasil jawaban responden yang diperoleh dari kuesioner, mayoritas menyatakan bahwa kepercayaan yang dimiliki oleh Shopee dinilai baik oleh responden. Tingkat respon paling tinggi terdapat pada item pernyataan "Aplikasi Shopee ini lebih terpercaya dibandingkan marketplace lain". Dapat diartikan bahwa responden setuju pada aplikasi Shopee dapat dipercaya dibandingkan dengan marketplace lain. Shopee memiliki jaminan yang diberikan untuk konsumen yaitu salah satunya dengan bentuk layanan bahwa konsumen berhak mendapatkan garansi pengembalian uang jika barang yang diterima tidak sesuai dengan yang di-order. Selain itu, Shopee juga bekerja sama dengan jasa layanan pengiriman barang yang ratingnya cukup baik yaitu J\&T Express. Hal ini perlu dipertahankan oleh aplikasi Shopee dalam memberikan kepercayaan kepada konsumen untuk menjaga citra perusahaan agar tetap lebih unggul dari marketplace lain. Dilihat dari hasil karakteristik responden, penelitian ini lebih banyak wanita berusia 19-27 tahun yaitu seorang mahasiswi. Hal tersebut terjadi karena perempuan lebih senang melakukan kegiatan belanja online melalui aplikasi Shopee karena aplikasi tersebut memiliki tingkat kepercayaan konsumen yang baik dalam hal keamanan dan pelayanan dibandingkan marketplace lain.

\section{Pengaruh Kemudahan terhadap Keputusan Pembelian}

Hasil penelitian membuktikan variabel kemudahan memiliki pengaruh terhadap keputusan pembelian. Sesuai konsep teori Turban et al. (2015:408), kemudahan memiliki hubungan dengan keputusan pembelian online. Sehingga, aplikasi Shopee memberikan kemudahan yang utama kepada konsumen melalui peningkatan fitur yang menarik dan memudahkan konsumen untuk menemukan produk juga memudahkan untuk melakukan transaksi pembelian di aplikasi Shopee. Sejalan dengan penelitian Rachmawati et al. (2020) kemudahan secara positif memengaruhi keputusan pembelian. Namun tidak sama dengan penelitian Hernandez et al. (2009) bahwa kemudahan memiliki hasil yang sebaliknya yaitu tidak berpengaruh. 
Dian Agustiningrum \& Anik Lestari Andjarwati. Pengaruh Kepercayaan, Kemudahan, dan Keamanan terhadap Keputusan Pembelian di Marketplace

Mayoritas jawaban responden menyatakan bahwa kemudahan yang dimiliki oleh Shopee dinilai baik oleh responden. Tingkat respon paling tinggi terdapat pada butir pernyataan "Saya merasa mudah menggunakan aplikasi Shopee untuk menemukan apa yang saya inginkan". Dapat diartikan bahwa responden setuju pada aplikasi Shopee memudahkan responden untuk menemukan apa yang diinginkan dalam menggunakan aplikasi tersebut. Aplikasi Shopee menyediakan berbagai layanan fitur yang menarik untuk mempermudah konsumen dalam mencari produk. Fitur yang beragam dan lebih mudah dan informasi yang jelas dapat menarik konsumen untuk menggunakan aplikasi tersebut. Hal ini harus dipertahankan oleh aplikasi Shopee untuk memudahkan konsumen dalam menemukan produk yang diinginkan, karena berhubungan dengan kenyamanan yang dirasakan pelanggan. Penelitian ini didominasi oleh wanita yang memiliki usia 19-27 tahun yaitu seorang mahasiswi. Hal tersebut karena seorang perempuan lebih senang melakukan pembelian melalui aplikasi Shopee karena aplikasi tersebut menyediakan berbagai fitur menarik yang mudah digunakan dan lebih dapat menghemat waktu konsumen untuk melakukan pembelian online. Kemudahan berpengaruh besar terhadap keputusan pembelian dalam penelitian yang dilaksanakan.

\section{Pengaruh Keamanan terhadap Keputusan Pembelian}

Penelitian menunjukkan hasil bahwa variabel keamanan berpengaruh terhadap keputusan pembelian. Hasil penelitian ini sesuai dengan konsep teori Turban et al. (2015:408) keamanan berpengaruh pada keputusan pembelian online. Aplikasi Shopee memberikan keamanan yang utama kepada konsumen melalui peningkatan fitur keamanan seperti keamanan dalam berinteraksi dengan penjual maupun keamanan dalam melakukan transaksi. Hasil penelitian ini mendukung Raman \& A (2011) yang menyatakan bahwa keamanan memengaruhi keputusan pembelian. Namun bertentangan dengan penelitian Irawan (2018) keamanan tidak berpengaruh pada keputusan pembelian. Hal ini dikarenakan memiliki perbedaan obyek yang digunakan dalam penelitian masing-masing.

Berdasarkan jawaban responden, mayoritas menyatakan bahwa keamanan yang dimiliki oleh Shopee dinilai baik oleh responden. Tingkat respon paling tinggi terdapat pada butir pernyataan "Saya merasa aman dalam transaksi saya dengan aplikasi Shopee". Responden setuju pada aplikasi Shopee karena memberikan keamanan responden dalam melakukan transaksi di Shopee. Keamanan merupakan hal utama yang diperhatikan konsumen pada saat melakukan kegiatan belanja online. Aplikasi Shopee memberikan jaminan keamanan data maupun transaksi untuk konsumennya melalui fitur pengembalian dana jika terjadi suatu hal yang tidak diinginkan. Dengan ini, konsumen tidak merasa khawatir karena pelayanan yang diberikan sudah menjamin keamanan pribadi. Hal ini perlu dipertahankan oleh aplikasi Shopee untuk menjaga keamanan dan kenyamanan konsumen dalam melakukan transaksi. Responden didominasi oleh wanita dengan usia 19-27 tahun yaitu seorang mahasiswi. Hal ini dikarenakan perempuan lebih meperhatikan keamanan yang diberikan marketplace, seperti dalam melakukan transaksi di aplikasi Shopee konsumen diberikan fasilitas keamanan yang terjamin seperti pihak Shopee menahan dana konsumen setelah barang diterima dan jika tidak sesuai dengan pesanan konsumen, Shopee menyediakan fitur pengembalian dana kepada konsumen. Sehingga, konsumen tidak kehilangan dana yang dikeluarkan untuk barang yang tidak sesuai. Hal tersebut sangat diperhatikan oleh aplikasi Shopee untuk tetap menjaga keamanan dan kepercayaan konsumen.

\section{KESIMPULAN}

Kepercayaan, kemudahan, dan keamanan terbukti memiliki pengaruh positif dan signifikan terhadap keputusan pembelian. Penelitian ini memiliki keterbatasan dalam hal penyebaran angket yang dilakukan secara online. Selain itu, penelitian ini tidak menyediakan angket terbuka, sehingga pembahasan mengenai variabel kurang mendalam. Penelitian selanjutnya dapat melibatkan variabel repurchase intention atau menggunakan metode yang berbeda seperti analisis konten untuk pembahasan yang lebih mendalam.

Implikasi praktis dari hasil penelitian ini aplikasi Shopee diharapkan lebih meningkatkan kualitas layanan melalui hal yang dirasakan konsumen dengan cara merespon ulasan konsumen tentang aplikasi Shopee dari segi kepercayaan, kemudahan, dan keamanan atau hal yang lain apabila dirasa 
kurang memuaskan. Hal ini disarankan agar tetap mempertahankan loyalitas konsumen. Aplikasi Shopee juga harus dapat mempertahankan kemudahan penggunaan aplikasi seperti pengembangan fitur terbaru yang lebih menarik dan praktis untuk lebih mempermudah konsumen dalam melakukan pencarian produk hingga memutuskan untuk melakukan transaksi. Variabel kemudahan lebih memiliki pengaruh besar terhadap keputusan pembelian daripada kepercayaan dan keamanan. Apabila kemudahan penggunaan yang dirasakan konsumen untuk menggunakan aplikasi Shopee lebih mudah, keinginan konsumen untuk menggunakan aplikasi tersebut juga dapat meningkat.

\section{DAFTAR PUSTAKA}

Abraham, W. (2020). Sejarah Awal berdirinya Marketplace Tokopedia, Shopee, Bukalapak, Lazada, Blibli dan JDID. Teknologi.Id. (https://teknologi.id/os/sejarah-awal-berdirinya-marketplacetokopedia-Shopee-bukalapak-lazada-blibli-dan-jdid, di akses pada 13 November 2020)

Aggarwal, A., \& Rahul, M. (2018). The Effect of Perceived Security on Consumer Purchase Intensions in Electronic Commerce. International Journal of Public Sector Performance Management, 4(1), 1-20. https://doi.org/10.1504/IJPSPM.2018.10009501

Chin, A. J., Wafa, S. A. W. S. K., \& Ooi, A.-Y. (2009). The Effect of Internet Trust and Social Influence towards Willingness to Purchase Online in Labuan, Malaysia. International Business Research, 2(2). 72-81 https://doi.org/10.5539/ibr.v2n2p72

Cindy, M. (2020). Riset: Belanja Online Indonesia Tumbuh 3,7 Kali Lipat di 2025. Katadata.Co.Id. (https://katadata.co.id/ekarina/digital/5e9a495b679e8/riset-belanja-online-indonesia-tumbuh37-kali-lipat-di-2025, diakses pada 13 November 2020)

Databoks, K. (2020). Peta Persaingan E-Commerce di Indonesia Kuartal II tahun 2020. Databoks. (https://databoks.katadata.co.id/datapublish/2020/09/21/peta-persaingan-e-commerceindonesia-pada-kuartal-ii-2020\#: :text=Shopee menguasai pasar e-commerce,pertama di AppStore dan Playstore, diakses pada 13 November 2020)

Davis, F. D. (1989). Perceived Usefulness, Perceived Ease of Use, and User Acceptance of Information Technology. MIS Quarterly: Management Information Systems, 13(3), 319-339. https://doi.org/10.2307/249008

Devaraj, S., Fan, M., \& Kohli, R. (2003). E-loyalty: Elusive Ideal or Competitive Edge? Communications of the ACM, 46(9), 184-191. https://doi.org/10.1145/903893.903936

Flavián, C., \& Guinalíu, M. (2006). Consumer Trust, Perceived Security and Privacy Policy: Three Basic Elements of Loyalty to a Web Site. Industrial Management \& Data Systems, 106(5), 601-620. https://doi.org/10.1108/02635570610666403

Hernandez, B., Jimenez, J., \& Jose Martin, M. (2009). The Impact of Self-Efficacy, Ease of Use and Usefulness on E-Purchasing: an Analysis of Experienced E-Shoppers. Interacting with Computers, 21(1-2), 146-156. https://doi.org/10.1016/j.intcom.2008.11.001

Husain, A. (2020). Riset Snapchart: Shopee paling diminati dan jadi pilihan konsumen belanja. Kontan.Co.Id.(https://industri.kontan.co.id/news/riset-snapcart-Shopee-paling-diminati-danjadi-pilihan-konsumen-berlanja, diakses pada 13 November 2020)

Iprice. (2020). Peta E-Commerce Indonesia. Iprice. (https://iprice.co.id/insights/mapofecommerce/, diakses pada 15 November 2020)

Irawan, I. A. (2018). Effect of Trust, Convinience, Security and Quality of Service on Online 
Dian Agustiningrum \& Anik Lestari Andjarwati. Pengaruh Kepercayaan, Kemudahan, dan Keamanan terhadap Keputusan Pembelian di Marketplace

Purchase Decision (Consumer Case Study in Tangerang Selatan Area). Jurnal Ekonomi, 23(1), 114-122. https://doi.org/10.24912/je.v23i1.337

Kolsaker, A., \& Payne, C. (2002). Engendering Trust in E-Commerce: a Study of Gender Based Concerns. Marketing Intelligence \& Planning, 20(4), 206-214. https://doi.org/10.1108/02634500210431595

Koufaris, M., \& Hampton-Sosa, W. (2004). The Development of Initial Trust in an Online Company by New Customers. Information and Management, 41(3), 377-397. https://doi.org/10.1016/j.im.2003.08.004

Malhotra, N. K. (2017). Riset Pemasaran Pendekatan Terapan (Edisi Keempat). Jakarta: Indeks.

Martínez, P., \& Rodríguez del Bosque, I. (2013). CSR and Customer Loyalty: The Roles of Trust, Customer Identification with the Company and Satisfaction. International Journal of Hospitality Management, 35, 89-99. https://doi.org/10.1016/j.ijhm.2013.05.009

Mbete, G. S., \& Tanamal, R. (2020). Effect of Easiness, Service Quality, Price, Trust of Quality of Information, and Brand Image of Consumer Purchase Decision on Shopee Online Purchase. $\begin{array}{lllll}\text { Jurnal Informatika Universitas } & \text { Pamulang, }\end{array}$ https://doi.org/10.32493/informatika.v5i2.4946

McKnight, D. H., Choudhury, V., \& Kacmar, C. (2002). Developing and Validating Trust Measures for E-Commerce: an integrative typology. Information Systems Research, 13(3), 334-359. https://doi.org/10.1287/isre.13.3.334.81

Osly, U., \& Choirunnisa. (2017). Influence Of Trust, Ease, Quality Of Information, And Display Product On Purchase Decision In Social Media. BMC Public Health, 5(1), 1-8. http://dx.doi.org/10.1016/j.jana.2015.10.005

Rachmawati, I. K., Hidayatullah, S., Nuryanti, F., \& Wulan, M. (2020). The Effect of Consumer Confidence on The Relationship Between Ease of Use and Quality of Information on Online Purchasing Decisions. International Journal of Scientific and Technology Research, 9(4), 774778. https://doi.org/10.2139/ssrn.3768103

Raman, A., \& A, V. (2011). Web Services and e-Shopping Decisions: a Study on Malaysian eConsumer. IJCA Special Issue on:Wireless Information Networks \& Business Information System. February 2011, 54-60. https://doi.org/10.1007/s10257-004-0040-8

Smith, T. J. (2008). Senior Citizens and E-Commerce Websites: The Role of Perceived Usefulness, Perceived Ease of Use, and Web Site Usability. Informing Science, 11, 59-83. https://doi.org/10.28945/440

Suhardi, D., \& Taufik, N. (2018). The Analysis of Ease of Use, Trust, and Website Quality towards Purchasing Decision in Lazada.co.id. Indonesian Journal Of Business And Economics, 1(1), 38-48. https://doi.org/10.25134/ijbe.v1i1.1358

Turban, E., King, D., Lee, J. K., Liang, T.-P., \& Turban, D. C. (2015). Electronic Commerce - A Managerial and Social Perspective. Switzerland: Springer International Publishing. http://www.springer.com/gp/book/9783319100906

Venkatesh, V. (2000). Determinants of Perceived Ease of Use: Integrating Control , Intrinsic Motivation, Acceptance Model. Inorganic Chemistry Communications, 11(3), 319-340. https://doi.org/10.1287/isre.11.4.342.11872 
Yenisey, M. M., Ozok, A. A., \& Salvendy, G. (2005). Perceived Security Determinants in ECommerce Among Turkish University Students. Behaviour and Information Technology, 24(4), 259-274. https://doi.org/10.1080/0144929042000320992 